\title{
Evaluation of canal transportation and centering ability of two nickel-titanium rotary instruments
}

\author{
- Sandra Soares Kühne Busquim Discipline of Endodontics, Department of Restorative Dentistry, School of Dentistry, \\ University of São Paulo, São Paulo, SP, Brazil • Rodrigo Casasanta França Discipline of Endodontics, Department of \\ Esthetic Dentistry, School of Dentistry, University of São Paulo, São Paulo, SP, Brazil • Evandro Luiz Siqueira Discipline \\ of Endodontics, Department of Restorative Dentistry, School of Dentistry, University of São Paulo, São Paulo, SP, Brazil \\ - Marcelo dos Santos Discipline of Endodontics, Department of Esthetic Dentistry, School of Dentistry, University of São \\ Paulo, São Paulo, SP, Brazil
}

ABSTRACT | Introduction: Rotary nickel-titanium (NiTi) instruments have become very popular in recent years mainly because they allow an efficient preparation of the root canal system. New rotary endodontic instruments resulted from the development of new features, such as variable taper, non-cutting safety tip and variable length of cutting blades. The purpose of this study was to evaluate the degree of canal transportation observed with two nickel-titanium rotary systems, $\mathrm{K}_{3}$ (SybronEndo, Orange, CA, USA) and Mtwo (VDW, Munich, Germany), as well as their centering ability, by measuring dentin wall thickness before and after instrumentation. Methods: Thirty extracted mandibular molars were embedded in resin blocks and sectioned 3.5 and $5.0 \mathrm{~mm}$ short of the anatomical apex. The mesiobuccal canals were prepared with the $\mathrm{K}_{3}$ system, using instruments $0.12 / 25,0.08 / 25,0.06 / 25,0.04 / 25$, and 0.02/30 progressively until reaching the working length; and the mesiolingual canals were prepared with the Mtwo system, using instruments $0.04 / 10,0.05 / 15,0.06 / 20$, and $0.06 / 25$ to full working length. Pre- and postoperative sections were photographed and all data were recorded and analyzed statistically using the Mann-Whitney test. Results: Canal transportation and centering ability results were similar for both instruments $(p>0.05)$. Relevance: The $\mathrm{K}_{3}$ and Mtwo systems allowed the preparation of curved root canals with minimal transportation, 3.5 or $5.0 \mathrm{~mm}$ short of the anatomical apex.

DESCRIPTORS | Root Canal Preparation; Dental Instruments; Dental Alloys.

RESUMO | Avaliação do transporte apical e da capacidade de centralização de dois sistemas rotatórios de niquel-titânio • Introdução: Os instrumentos rotatórios em níquel titânio vêm se tornando populares nos últimos anos principalmente devido à sua eficiência no preparo de canais radiculares. Novos instrumentos rotatórios resultaram do desenvolvimento de características como conicidade, pontas sem corte seguras, e variação do comprimento da lâmina de corte. A proposta deste estudo foi avaliar o grau de transporte do canal observado com dois sistemas rotatórios de níquel-titânio, K3 (SybronEndo, Orange, CA, EUA) e Mtwo (VDW, Munique, Alemanha), bem como sua habilidade de centralização, por meio da mensuração dos fragmentos de dentina da parede do canal radicular, antes e após a instrumentação. Métodos: Trinta molares inferiores foram inseridos em blocos de resina e seccionados a 3,5 e a 5,0 mm do ápice. Os canais mésio-vestibulares foram preparados com o sistema K3 utilizando-se a sequência \#25.12, \#25.08, \#25.06, \#25.04 e \#30.02 progressivamente até o comprimento de trabalho; e os canais mésio-linguais foram preparados com o sistema Mtwo, utilizando-se os instrumentos \#10.04, \#15.05, \#20.06 e \#25.06 por todo o comprimento de trabalho. Secções pré e pós-operatória foram fotografadas, e todos os dados foram anotados e analisados estatisticamente utilizando-se o teste de Mann-Whitney. Resultados: Os resultados referentes ao grau de transporte do canal e à capacidade de centralização foram similares para ambos os sistemas $(p>0.05)$. Relevância: Os sistemas K3 e Mtwo permitiram o preparo de canais curvos com mínimo transporte a 3,0 ou a 5,0 mm do ápice anatômico.

DESCRITORES | Preparo de Canal Radicular; Instrumentos Odontológicos; Ligas Dentárias.

CORRESPONDING AUTHOR

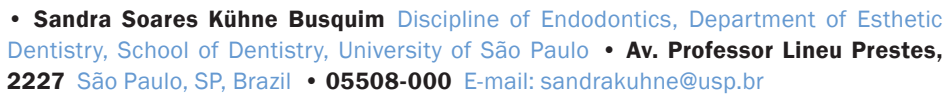

- Sandra Soares Kühne Busquim Discipline of Endodontics, Department of Esthetic Dentistry, School of Dentistry, University of São Paulo • Av. Professor Lineu Prestes, 2227 São Paulo, SP, Brazil • 05508-000 E-mail: sandrakuhne@usp.br

- Received Apr 03, 2013 • Accepted Apr 18, 2013 


\section{INTRODUCTION}

Rotary nickel-titanium (NiTi) instruments have become very popular in recent years mainly because they allow an efficient preparation of the root canal system. Owing to its superior elasticity and high flexibility, the NiTi alloy allows the instruments to efficiently follow the root canal's original path. ${ }^{1-3}$

The cutting ability of root canal instruments is a complex interrelationship of parameters such as cross-sectional design, chip removal capacity, helical and rake angle, metallurgical properties and surface treatment. ${ }^{4-6}$ New rotary endodontic instruments resulted from the development of new features, such as variable taper, non-cutting safety tip and variable lengths of cutting blades. The $\mathrm{K}_{3}$ rotary instruments (SybronEndo, Orange, CA, USA) are three-fluted files of constant taper with a slight positive rake angle for cutting efficiency., 3,7 The Mtwo rotary instruments (VDW, Munich, Germany) have deep cutting blades, a non-cutting tip and minimum radial canal wall contact for safe and fast preparation. ${ }^{9}$ Although the $\mathrm{K} 3$ system presents three radial lands, which allow the operator more control by centering and stabilizing the instrument while rotating, avoiding the potential for canal transportation, the Mtwo system has deep cutting blades to reduce core diameter and increase flexibility, which leads to more effective cutting action with less tendency for canal transportation. ${ }^{9,10}$ Therefore, they have different features for reaching the same goal: avoiding canal transportation.

The purpose of this study was to evaluate whether the different features presented by the $\mathrm{K}_{3}$ and Mtwo systems enable different performance results regarding canal transportation and centering ability in curved root canals.

\section{MATERIAL AND METHODS}

Thirty extracted mandibular molars with degrees of curvature ranging between $25^{\circ}$ and $35^{\circ}$ according to Schneider ${ }^{11}$ were selected on the basis of the absence of noticeable defects and the presence of intact pulp chambers. All of them, after external cleaning, were autoclaved and cooled to room temperature. A thin layer of black nail polish (Colorama, São Paulo, Brazil) was applied to each root to enhance visualization of the external limits.

The coronary opening of each specimen was made with round diamond burs and Endo-Z burs (Dentsply Maillefer, Ballaigues, Switzerland). Restorative materials and compromised dental tissue were completely removed.

A modification of the Bramante method $^{12}-\mathrm{a}$ cross-sectional assessment of the root canal shapewas used. In this method, each tooth was fixed by its occlusal surface to a piece of number 7 pink wax (Asfer, São Caetano do Sul, Brazil) with a metallic guide, placed on the proximal surfaces to prevent misalignment after the serial cuts. Subsequently, PVC tubes (3/4 inch width and $3 \mathrm{~cm}$ height) were used to envelop each tooth/metallic guide and a fluid polyester resin (Resinfiber, São Paulo, Brazil) was poured to fill the tubes, and the resin was then cured at room temperature for twenty-four hours. ${ }^{12}$ Then the blocks were cut perpendicular to the root surface using a precision sectioning saw (Isomet 1000, Buehler, IL, USA), 3.5 and $5.0 \mathrm{~mm}$ short of the apex. Each section was properly numbered and the images were captured using QCapture (QImaging, Surrey, Canada) and digitally processed using Image $\mathrm{J} 1.43$ software (National Institutes of Health, Maryland, USA). The thickness of the dentin wall around the orifice of the mesial roots was measured. In each cross-section, the longest distances between the edges of the non-instrumented canals and the root edges were determined and measured in millimeters in both the mesial and distal directions, as shown in Figure 1.

The blocks were rebuilt, the metallic guides replaced, and the mesial canals of the samples were prepared. 
Figure 1 | Pre- and postinstrumentation images, $\mathbf{A}$ and

$\mathbf{B}$, respectively, showing how the studied measurements were taken on the mesial and distal portions

of each canal. MB: mesiobuccal canal; ML: mesiolingual canal. x1: distance between the mesial portions of the root and the non-instrumented canal; X2: distance between the mesial portions of the root and the instrumented canal; $\mathbf{y 1 :}$ distance between the distal portions of the root and the non-instrumented canal and y2: distance between the distal portions of the root and the instrumented canal.
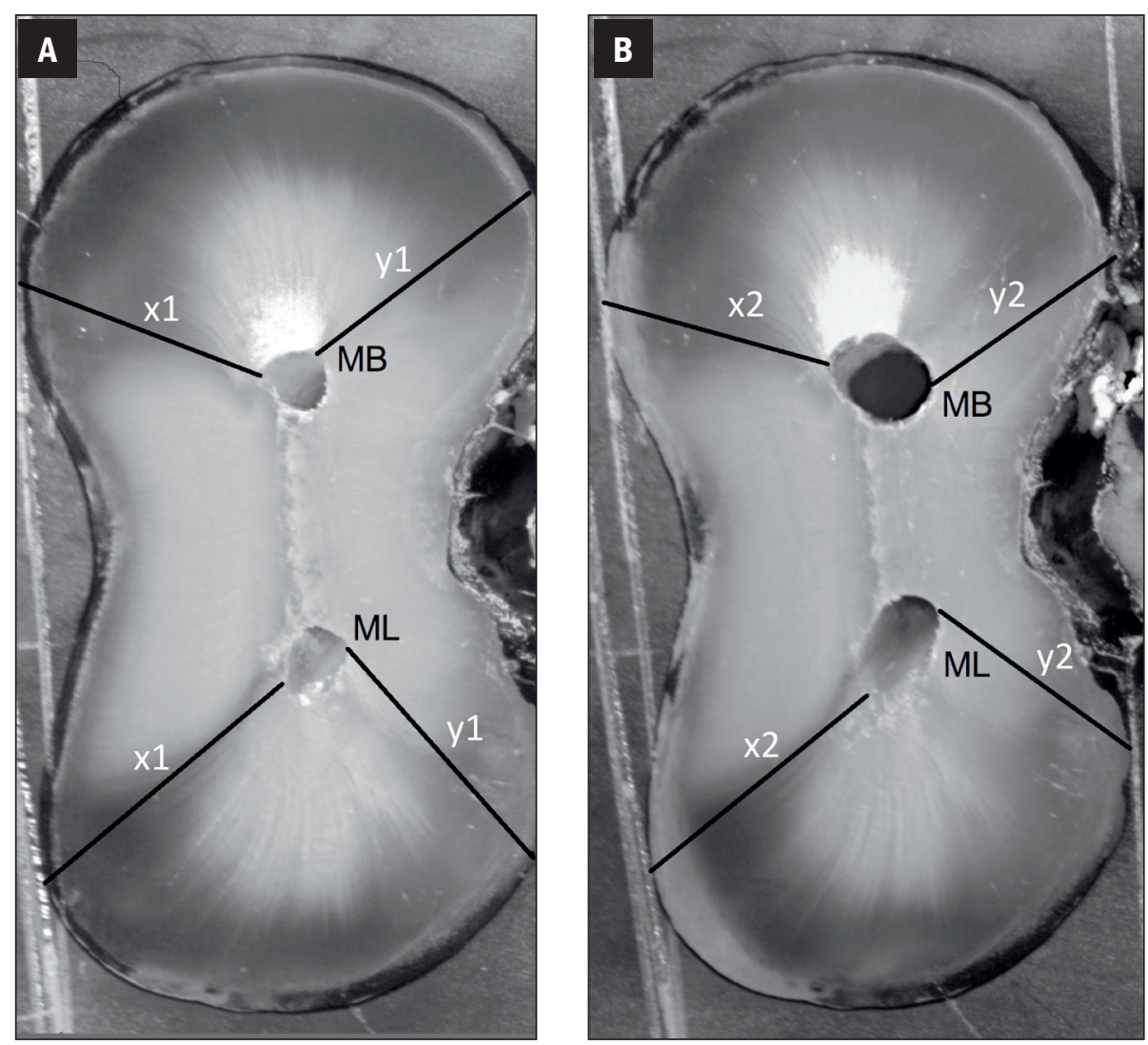

\section{Canal preparation}

Samples were prepared with the two different instrument systems using a torque-controlled electric motor (Nouvag AG TCM 3000, Goldach, Switzerland) at a constant rotation of $300 \mathrm{rpm}$.

Canals of both groups were copiously irrigated with $1.0 \%$ sodium hypochlorite. Patency was standardized by inserting a \#10 K-file (Dentsply Maillefer, Tulsa, USA) until the instrument tip became visible at the apical foramen with the help of an operating microscope (Alliance, São Paulo, Brazil) at $8 \times$ magnification. Individual working length was determined $1.0 \mathrm{~mm}$ short of this position. ${ }^{13}$

For the instrumentation of the mesiobuccal canals $(\mathrm{n}=30)$, the $\mathrm{K}_{3}$ (SybronEndo, Orange, CA, USA) instruments were used crown down with very little pressure, never forcing instruments to working length. When the instrument no longer advanced apically, we proceeded to the next file.
The instrument sequence followed was $0.12 / 25$, $0.08 / 25,0.06 / 25,0.04 / 25$ and $0.02 / 30$.

The mesiolingual canals $(\mathrm{n}=30)$ were prepared using the manufacturer's sequence for the Mtwo (VDW, Munich, Germany) instruments: 0.04/10, $0.05 / 15,0.06 / 20$ and $0.06 / 25$. This system requires the introduction of each instrument directly to working length, so slight in-and-out movement was applied gradually forcing each instrument apically.

\section{Image evaluation}

After root canal preparation, each canal was dried with sterile paper points and the sections were disassembled. New images were captured using QCapture and digitally processed using Image $\mathrm{J}$ 1.43 software. The measurements were taken using the same reference points as previously described. Canal transportation was calculated in millimeters 
Table 1 | Canal transportation and centering ratio $(\mathrm{mm})$ associated with the $\mathrm{K} 3$ and Mtwo systems (mean $\pm \mathrm{SD}$ ).

\begin{tabular}{c|c|c|c|c}
\hline $\begin{array}{c}\text { Cross- } \\
\text { section }\end{array}$ & \multicolumn{2}{|c|}{ Canal transportation } & \multicolumn{2}{c}{ Centering ratio } \\
\hline $3.5 \mathrm{~mm}$ & $0.210 \pm 0.050$ & $0.174 \pm 0.059$ & $0.525 \pm 0.198$ & $0.510 \pm 0.300$ \\
\hline $5.0 \mathrm{~mm}$ & $0.184 \pm 0.016$ & $0.149 \pm 0.026$ & $0.660 \pm 0.201$ & $0.535 \pm 0.343$ \\
\hline
\end{tabular}

and determined using the following formula according to Gambill et al. ${ }^{14}$ :

$$
[(x 1-x 2)-(y 1-y 2)]
$$

A result of zero would indicate no canal transportation. The centering ratio, which measures the ability of the instrument to remain in a central position within the canal according to Gambill et al., ${ }^{14}$ was calculated as follows:

$$
(x 1-x 2) \text { to }(y 1-y 2)
$$

The smaller of the two numbers was used as the numerator for this formula. Using this formula, a result of 1 would indicate perfect centering. In both formulas, $\mathrm{x} 1$ corresponds to the distance between the mesial portions of the root and the non-instrumented canal; x2, the distance between the mesial portions of the root and the instrumented canal; $\mathrm{y} 1$, the distance between the distal portions of the root and the non-instrumented canal, and y2, the distance between the distal portions of the root and the instrumented canal.

\section{RESULTS}

The mean values \pm standard deviations of root canal transportation and centering ability produced by the $\mathrm{K}_{3}$ and Mtwo systems 3.5 and $5.0 \mathrm{~mm}$ short of the anatomical apex are shown in Table 1. The Mann-Whitney test indicated that there were no statistically significant differences between the systems with respect to canal transportation and centering ability ( $p>0.05)$. Analysis of the data re- garding canal transportation revealed a slight, but not statistically significant ( $p>0.05$ ), tendency for canal transportation toward the mesial portion of the canal for the $\mathrm{K}_{3}$ and Mtwo systems.

\section{DISCUSSION}

Nickel-titanium rotary instruments have become an important adjunct in endodontic therapy. When new instruments are introduced, several characteristics need to be investigated including cleaning ability, shaping ability, safety aspects and effects on root canal configuration. ${ }^{1,14}$ The $\mathrm{K}_{3}$ and Mtwo systems have different characteristics, features and operative sequence: the first system mentioned uses the crown-down technique, whereas the second employs the single-length technique. Few studies in the literature have assessed the shaping ability results of rotary Mtwo NiTi files compared to $\mathrm{K}_{3}$ instruments. ${ }^{10,15,16}$ This study attempted to evaluate whether the different features presented by these two systems enable different performance results with regard to canal transportation and centering ability in curved root canals.

Mandibular molars were selected and their mesial root canals were used because they provide a similar root canal angle and a homogeneous sample. Because of the shortcomings of acrylic resin blocks (surface texture, hardness and cross-section), natural teeth rather than simulated canals were used for a closer reproduction of actual clinical conditions. ${ }^{17-19}$

In the literature, many papers had already described a superior ability of NiTi files to maintain curvature in curved root canals because of the 
greater flexibility of these instruments. ${ }^{1,19}$ The geometrical shapes and dimensions of the NiTi rotary instruments may have an important effect on their behavior. The $\mathrm{K}_{3}$ instruments are designed with a slightly positive rake angle, a variable core diameter, three asymmetrical radial lands and a variable flute pitch. ${ }^{3,46}$ The Mtwo instruments, which have been introduced more recently, are characterized by an S-shaped cross-section, no radial lands, a small pitch increasing stability, a progressive pitch enhancing cutting ability and a steep helical angle. A small instrument core provides improvements in flexibility.,20,21

It is a known fact that an instrument's flexibility is very important when considering canal transportation. Transportation of the root canal is determined by the flexibility of the canal preparation instruments and the movement of the instrument in the canal. ${ }^{22}$ Even though the Mtwo system presents less core diameter and, consequently, better flexibility than the $\mathrm{K}_{3}$ system, no significant difference in canal transportation and centering ability was found according to the results of the present study. This fact can probably be explained by the presence of the radial lands in the $\mathrm{K}_{3}$ system, which stabilize the instrument and keep it centered in the root canal, compensating for the mass of the material.

The $\mathrm{K}_{3}$ system demonstrated less tendency for canal transportation at $3.5 \mathrm{~mm}$ than the Mtwo system, probably because the $\mathrm{K}_{3}$ instrument used last had a \#30 tip, whereas the Mtwo had a \#25 tip. This difference was allowed on purpose because the goal was to analyze the basic sequence of the Mtwo system proposed by the manufacturer for all canal anatomies (including curved root canals) and

\section{REFERENCES}

1. Glossen CR, Haller RH, Dove SB, del Rio CE. A comparison of root canal preparations using Ni-Ti hand, Ni-Ti engine the capability of properly shaping them. Despite this tendency, no statistically significant difference was detected between these parameters.

Our findings are comparable with those of previous papers by Sonntag et al..$^{10}$ and $\mathrm{Li} \mathrm{Z}$ et al. ${ }^{16}$ that demonstrated good preparation results and no significant difference in canal transportation when using $\mathrm{K}_{3}$ and Mtwo rotary NiTi instruments. On the other hand, Schäfer et al. ${ }^{15}$ found that the Mtwo system maintained the original canal curvature significantly better than the $\mathrm{K} 3$ system.

Bürklein \& Schäfer ${ }^{20}$ studied the Mtwo system and concluded that it was safe and suitable for preparing curved root canals with respect to maintenance of original canal shape in simulated curved canals. Schäfer \& Oitzinger ${ }^{6}$ found in their study that Mtwo and RaCe instruments had better cutting efficiency than other instruments, which could be explained by their distinct positive cutting angles and small core diameter. Sadeghi ${ }^{23}$ attributed better shaping ability to the Mtwo system compared to the FlexMaster system.

Although the shaping ability of an instrument represents only one selection criterion, information about canal transportation and centering ability may be of value, and should be considered in the selection of a particular rotary NiTi instrument.

In conclusion, the Mtwo system showed a behavior similar to that of the $\mathrm{K} 3$ system 3.5 and $5.0 \mathrm{~mm}$ short of the anatomical apex, with no statistically significant difference in canal transportation and centering ability results, despite their distinct features. Mtwo and $\mathrm{K}_{3}$ rotary systems properly prepared the mesial canals of extracted mandibular molars with only slight deviation.

driven, and K-Flex endodontic instruments. J Endod. 1995 Mar;21(3):146-51. 
2. Thompson SA. An overview of nickel-titanium alloys used in dentistry. Int Endod J. 2000 Jul;33(4):297-310.

3. Melo MC, Pereira ES, Viana AC, Fonseca AM, Buono VT, Bahia MG. Dimensional characterization and mechanical behaviour of $\mathrm{K}_{3}$ rotary instruments. Int Endod J. 2008 Apr;41(4):329-38.

4. Hülsmann M, Peters OA, Dummer PMH. Mechanical preparation of root canals: shaping goals, techniques and means. Endod Topics. 2005 Mar;10(1):30-76.

5. McSpadden JT. Mastering Endodontic Instrumentation. Chattanooga, TN, USA: Cloudland Institute; 2007. p. 34.

6. Schäfer E, Oitzinger M. Cutting efficiency of five different types of rotary nickel-titanium instruments. J Endod. 2008 Feb;34(2):198-200.

7. Foschi F, Nucci C, Montebugnoli L, Marchionni S, Breschi L, Malagnino VA, et al. SEM evaluation of canal wall dentine following use of Mtwo and ProTaper NiTi rotary instruments. Int Endod J. 2004 Dec;37(12):832-9.

8. Mounce RE. The K 3 rotary nickel-titanium file system. Dent Clin North Am. 2004 Jan;48(1):137-57.

9. Vahid A, Roohi N, Zayeri F. A comparative study of four rotary NiTi instruments in preserving canal curvature, preparation time and change of working length. Aust Endod J. 2009 Aug;35(2):93-7.

10. Sonntag D, Ott M, Kook K, Stachniss V. Root canal preparation with the NiTi systems $\mathrm{K}_{3}$, Mtwo and ProTaper. Aust Endod J. 2007 Aug;33(2):73-81.

11. Schneider SW. A comparison of canal preparations in straight and curved root canals. Oral Surg Oral Med Oral Pathol. 1971 Aug;32(2):271-5.

12. Bramante CM, Berbert A, Borges RP. A methodology for evaluation of root canal instrumentation. J Endod. 1987 May;13(5):243-5.

13. Freire LG, Gavini G, Branco-Barletta F, Sanches-Cunha R, dos Santos M. Microscopic computerized tomographic evaluation of root canal transportation prepared with twisted or ground nickel-titanium rotary instruments. Oral Surg Oral Med Oral Pathol Oral Radiol Endod. 2011 Dec;112(6):e143-8. 14. Gambill JM, Alder M, del Rio CE. Comparison of nickeltitanium and stainless steel hand-file instrumentation using computed tomography. J Endod. 1996 Jul;22(7):369-75.

15. Schäfer E, Erler M, Dammaschke T. Comparative study on the shaping ability and cleaning efficiency of rotary Mtwo instruments. Part 1. Shaping ability in simulated curved canals. Int Endod J. 2006 Mar;39:196-202.

16. Li Z, Yu JT, Shou FY, Li L, Wu HB. [Comparative study on the shaping ability of canals with 2 new nickel-titanium rotary instruments]. Shanghai Kou Qiang Yi Xue. 2010 Feb;19(1):100-3.

17. Thompson SA, Dummer PM. Shaping ability of ProFile.o4 Taper Series 29 rotary nickel-titanium instruments in simulated root canals. Part 1. Int Endod J. 1997 Jan;30:1-7.

18. Peters OA. Current challenges and concepts in the preparation of root canal systems: a review. J Endod. 2004 Aug;30(8):559-67.

19. Guelzow A, Stamm O, Martus P, Kielbassa AM. Comparative study of six rotary nickel-titanium systems and hand instrumentation for root canal preparation. Int Endod J. 2005 Oct;38(10):743-52.

20. Bürklein S, Schäfer E. The influence of various automated devices on the shaping ability of Mtwo rotary nickel-titanium instruments. Int Endod J. 2006 Dec;39(12):945-51.

21. Giovannone T, Migliau G, Bedini R, Ferrari M, Gallottini L. Shaping outcomes using two Ni-Ti rotary instruments in simulated canals. Minerva Stomatol. 2008 Apr;57(4):143-54.

22. Taşdemir T, Aydemir H, Inan U, Unal O. Canal preparation with Hero 642 rotary Ni-Ti instruments compared with stainless steel hand K-file assessed using computed tomography. Int Endod J. 2005 Jun;38(6):402-8.

23. Sadeghi S. Shaping ability of NiTi rotary versus stainless steel hand instruments in simulated curved canals. Med Oral Pathol Oral Cir Bucal. 2011 May;16(3):e454-8. 